\title{
Unemployment and the UK labour market before, during and after the Golden Age
}

\author{
TIMOTHY J. HATTON $\dagger$ AND GEORGE R. BOYER \\ †Australian National University and University of Essex \\ \$Cornell University
}

\begin{abstract}
During the 'golden age' of the 1950s and 1960s unemployment in Britain averaged 2 per cent. This was far lower than ever before or since and a number of hypotheses have been put forward to account for this unique period in labour market history. But there has been little attempt to isolate precisely how the determinants of wage setting and unemployment differed before, during and after the golden age. We estimate a two-equation model over the whole period from 1872 to 1999 using a newly constructed set of long-run labour market data. We find that the structure of real wage setting was different in the golden age, consistent with notions about the postwar consensus, but it did not result in wages that were significantly lower relative to productivity than during other eras. Rapid growth in productivity and world trade together with low interest rates did keep unemployment lower during the golden age than after the 1970s. But the key difference between the golden age and the periods before and after was shifts in labour demand that are not accounted for by any of the variables that are usually thought to determine the equilibrium unemployment rate.
\end{abstract}

\section{Introduction}

Between 1947 and 1973 the unemployment rate in Britain averaged a mere 2.1 per cent. On this key indicator, UK labour market performance was dramatically better than ever before or since. During the 1970s, as the unemployment rate crept inexorably upwards, there was a widely shared belief that the performance of the 1950s and 1960s was (or had become) the norm. Governments grappled with what they believed were exceptional circumstances, under the assumption that the conditions of the 'golden age' could be recreated. But as high rates of unemployment persisted throughout the 1980s and into the 1990s, the golden age began to look more and more

We are grateful for comments on an earlier version of this article from George Chouliarakis, participants at the Economic History Society Conference at Durham, April, 2003, the editors and two anonymous referees. 
like an anomaly - albeit one that lasted for quarter of a century. Comparisons with the interwar years and earlier only served to reinforce that point. In the last few years, with the fall in unemployment to levels last seen in the 1970s, there has been some speculation that Britain may be entering a new era of sustained low unemployment reminiscent of the 'golden age'.

A fundamental premise of this article is that such long-term shifts in average unemployment rates need to be studied in an appropriately longterm context. While there is a large econometric literature that seeks to explain the rise in unemployment since the 1960s, very few observers have pushed the analysis further back in time. On the other hand, historical studies that examine the period before 1914 or the interwar period in isolation completely miss the fundamental shifts in labour market performance across the two World Wars. ${ }^{1}$ Here we examine a new database that we have developed of historically-consistent labour market series going back to 1870 . With this we can compare and contrast the golden age of the 1950s and 1960s with periods both before and after in order more precisely to isolate whether, and if so why, the performance of the golden age was so different from the rest of UK labour market history.

The next section looks at key indicators that might be expected to determine unemployment over broad economic eras. This is followed by a discussion of several potential explanations for the unusually low unemployment during the golden age. We then set out a two-equation model from which the Non-Accelerating Inflation Rate of Unemployment (NAIRU) can be derived. These equations are estimated using our long-run dataset and the NAIRU, calculated for 1948-1971, is compared with that for other periods under different counterfactual assumptions. Finally, we examine the effects of economic trends in the 1970s when the golden age seems to have evaporated. Our findings are summed up in a short conclusion.

\section{Unemployment in the long run}

Our long-run consistent unemployment series is plotted in Figure 1. This series differs a little from those previously available, especially before World War 1. Between 1946 and 1973 unemployment was always lower than the lowest rate recorded in any other period, with the exception of the few years of intense boom and inflation immediately after World War 1 . The interwar years and the period from 1974 onwards exhibit very high unemployment rates with wide fluctuations, while before 1913 both the mean and the amplitude were somewhat lower. The most important point stemming from Figure 1 is that patterns of unemployment differ sharply across periods of

${ }^{1}$ Hatton (1988), Broadberry (1994) and Bianchi and Zoega (1997) are among the few studies that estimate models of unemployment that span two or more of these economic eras. 


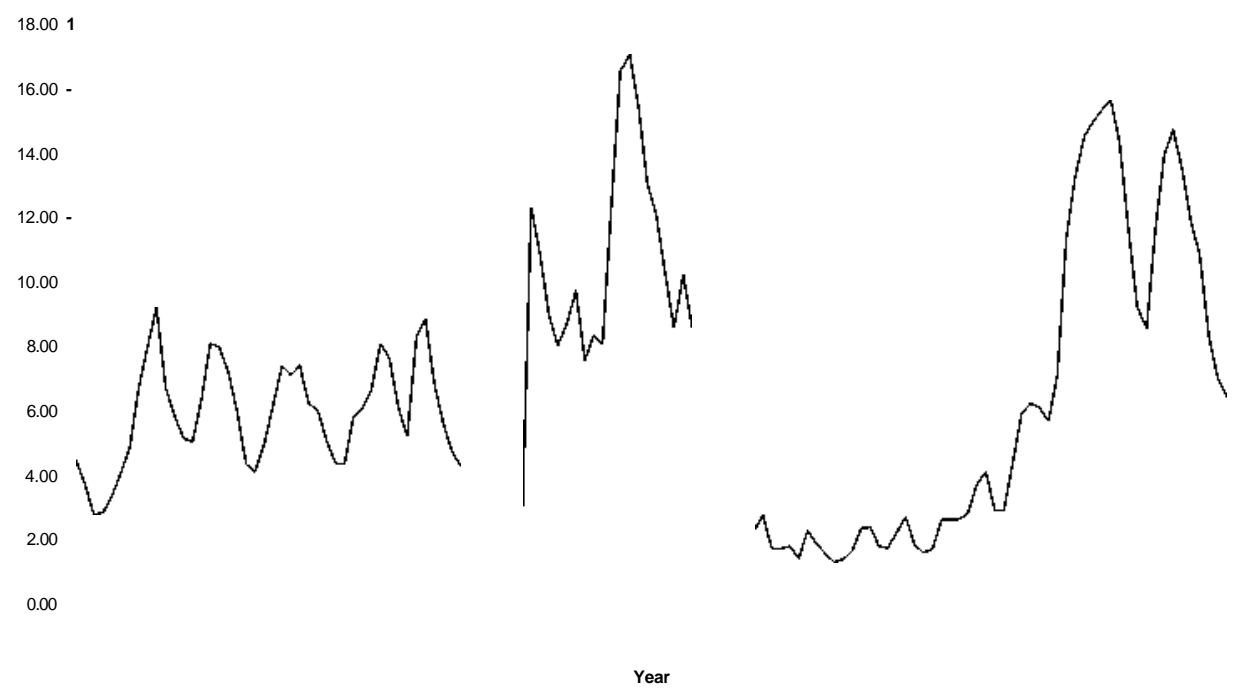

Figure 1. UK unemployment rate, 1870-1999.

20 years or more, and it is the differences between these periods, rather than variations within each, that demand explanation. Accordingly Table 1 provides averages of key indicators for five periods between 1871 and 1999. The means and standard deviations of the unemployment rate speak for themselves, but these major periods differ in other ways too. Nominal wages and prices were relatively stable before the First World War, and drifted downwards from 1921. By contrast there was persistent inflation in the postwar period, gradually accelerating until the mid-1970s.

Table 1 also includes a number of variables that have typically been used in studies of unemployment and for which we have derived long-run series that are as consistent as possible over the long run. Much attention has been lavished on the unemployment benefit replacement ratio (Benjamin and Kochin 1979, Minford 1983). From 1921 it represents the weekly rate of unemployment insurance benefit for a man claiming for a wife and two children relative to the average manual wage rate. Before the First World War it is the average rate of unemployment benefit for males in trade unions that operated benefit funds, also relative to the average manual wage. On this measure the replacement rate was slightly lower during the golden age than it was either in the interwar period or after 1973. But as has been pointed out, these differences seem too small to explain much of the large shift in unemployment performance between the interwar period and the early postwar period, or between the golden age and the post-1973 period (Metcalf et al. 1982). Before the First World War our calculated replacement rate for trade unionists is broadly similar to the unemployment insurance rates for later periods. It fell slightly over time as nominal wage rates rose. 
Table I. Five economic eras.

\begin{tabular}{|c|c|c|c|c|c|}
\hline & $1871-1891$ & $1892-1913$ & $1921-1938$ & 1947-1973 & 1974-1999 \\
\hline Unemployment rate $(\%)$ & $5-5$ & 6.2 & 10.9 & 2.1 & 10.1 \\
\hline $\begin{array}{l}\text { Standard deviation of } \\
\text { unemployment rate }\end{array}$ & 1.83 & 1.31 & 3.00 & 0.69 & 3.88 \\
\hline $\begin{array}{l}\text { Average rate of price } \\
\text { inflation ( } \% \text { p.a.) }\end{array}$ & -0.4 & 0.5 & -2.4 & 4.6 & $7-4$ \\
\hline $\begin{array}{l}\text { Average rate of wage } \\
\text { inflation (\% p.a.) }\end{array}$ & 0.9 & 1.2 & -1.6 & $7-2$ & 8.8 \\
\hline Replacement rate $(\%)$ & 51.8 & $43-3$ & 51.6 & $45-3$ & 48.4 \\
\hline $\begin{array}{l}\text { Percentage of labour } \\
\text { force covered by } \\
\text { benefit schemes }\end{array}$ & 2.6 & $7-i$ & 65.9 & 99.0 & 100.0 \\
\hline Trade union density (\%) & 6.1 & 13.0 & 27.1 & $44-4$ & $4 i-7$ \\
\hline $\begin{array}{l}\text { Coverage of national } \\
\text { collective bargaining (\%) }\end{array}$ & - & 10.4 & 42.3 & 72.0 & 65.3 \\
\hline $\begin{array}{l}\text { Fuel price index/GDP } \\
\text { deflator }(1913=100)\end{array}$ & 70.1 & 82.8 & 92.1 & 193.6 & 304.2 \\
\hline $\begin{array}{l}\text { Import price/GDP } \\
\text { deflator }(1913=100)\end{array}$ & 119.0 & 97.6 & 68.4 & 83.5 & 69.0 \\
\hline $\begin{array}{l}\text { Income tax and social } \\
\text { insurance contributions/ } \\
\text { nominal GDP }(\%)\end{array}$ & 1.1 & 1.8 & 10.3 & 18.9 & 23.4 \\
\hline $\begin{array}{l}\text { Labour productivity } \\
\text { growth (\% p.a.) }\end{array}$ & 1.07 & 0.77 & 1.55 & 2.40 & 1.69 \\
\hline Structural change index & 2.26 & 1.97 & 4.04 & 2.33 & 2.24 \\
\hline Real interest rate $(\%)$ & 3.49 & 2.39 & 5.70 & 1.25 & 2.66 \\
\hline $\begin{array}{l}\text { Growth of world trade } \\
\text { volume ( } \% \text { p.a.) }\end{array}$ & 3.73 & 3.31 & 2.08 & 7.43 & 4.44 \\
\hline
\end{tabular}

Sources: See Appendix.

However, only a very small proportion of the labour force was covered by these schemes. With the advent of unemployment insurance, coverage expanded to about two-thirds of the labour force during the interwar period, becoming universal from 1948.

Much has also been made of the effects of trade unions, which, by bargaining up the wage, created higher unemployment. Before the First World War unionism was patchy and it increased in fits and starts, with overall density reaching 22 per cent in 1913 . Unionism increased sharply during the First World War to a peak of 45 per cent in 1920 before a gradual decline set in. The peak of 1920 was recovered and sustained during the golden age, rising to 53 per cent in 1978 before declining during the Thatcher era. While the post-Thatcher decline in the strength of trade unions has been linked with improved unemployment performance, this hypothesis does not look so promising in a longer-term perspective. The period when unionism was sustained at its highest level was precisely the time when unemployment was at its lowest. Looking at the coverage of collective bargaining rather than at union membership reinforces that point. The coverage of national collective 
agreements increased by 30 percentage points between the interwar period and the golden age, eventually declining during the 1980s.

Some observers point to other variables that drive a wedge between employers' costs and net real wages as a source of wage resistance that can create unemployment. Several of these 'wedge' terms are included in Table 1. The share of direct tax in national income (as measured by income tax and National Insurance contributions, not all of which would have fallen on labour) increased across the eras with the major hikes occurring across the two world wars. The ratio of import prices to the GDP deflator fell across the First World War and then increased between the interwar period and the golden age. Insofar as lower import prices reduce the cost of living relative to output prices, this should have reduced wage pressure during the interwar period and in the post-1973 period as compared with the golden age or the period before 1913. Yet these were precisely the eras when unemployment was highest.

In addition it is often argued that the sharp rise in fuel prices that occurred with the oil shocks of the 1970s increased costs and reduced employment. The fuel price index in Table 1 is a weighted average of the crude oil price and the pithead price of coal relative to the GDP deflator, with the weights reflecting the changing composition of energy use. While this index increases by about 50 per cent between the golden age and the post- 1973 periods, there is an even sharper increase in the relative fuel price (mainly coal) of 100 per cent between the interwar period and the golden age.

Thus while some of these wedge terms may help explain the rise in unemployment across the 1970s (particularly oil prices), like the variables previously discussed, they move in the wrong direction to help explain why unemployment fell so dramatically across the Second World War. Thus Broadberry (1994, p. 246) finds that the model estimated by Layard and Nickell (1985) for the postwar period predicts that unemployment should have been even lower in the interwar period than it was in the early postwar years.

\section{Alternative hypotheses}

As previous observers have noted, it is hard to explain the broad sweep of British labour market history in terms of the wage pressure variables and/or relative price effects. There seem to be two alternative hypotheses. The first is that there are other variables, omitted from the discussion so far, which had effects sufficiently powerful that they more than offset the negative effects of wage pressure variables during the golden age as compared with other periods. The second is that the forces that would normally raise the equilibrium unemployment level were suspended or went into abeyance during the golden age, such that there was a shift in the relationship between unemployment and its determinants in that period as compared with all others. 
Some variables representing the first hypothesis are included at the bottom of Table i. One possibility is that structural change was slower or somehow more benign during the golden age than in the adjacent periods. The structural change index measures structural shifts between 12 sectors that comprise the whole economy and it is similar in principle to that used by Matthews et al. (1982). But here it is calculated on an annual basis and it therefore represents short-run turbulence rather than medium-term structural change. As the Table shows, structural change was greater on average during the interwar period than at other times, supporting the views of some economic historians (for instance, Booth and Glynn 1975). But across the other eras it seems to have been broadly similar, despite considerable annual variation within each period.

Another candidate is labour productivity growth. As outlined further below, faster productivity growth can reduce unemployment if employment depends on the 'gap' between the real wage and labour productivity, and if the real wage adjusts only slowly to current productivity. This approach has been invoked to explain high unemployment in response to productivity shocks in the 1920s (Broadberry 1990) and in the 1970s (Bruno and Sachs 1985), and it has recently returned to prominence (Ball and Moffitt 2001, Ball and Mankiw 2002). As Table 1 shows, labour productivity grew faster during the golden age than over any other period of comparable length. It therefore seems capable of explaining some of the cross-period differences in average unemployment rates.

It has also been argued - most famously by Matthews (1968) - that aggregate demand was higher and more stable during the 1950s and 1960s than in the preceding eras. However, that view neglects the supply side and begs the question of why a high level of aggregate demand was not quickly translated into price and wage inflation that ultimately restored the level of unemployment to its pre-existing equilibrium level. One possibility is that demand shocks were more often positive during the golden age than at other times. A crude measure of external demand shocks is the rate of growth of world trade. As Table 1 shows, world trade grew at an average rate of between 3 and 4 per cent up to 1913 and then a series of negative shocks reduced its average growth rate in the well-known deglobalisation process that took place during the interwar period. But between 1948 and 1973 the volume of world trade grew at twice the rate of the earlier era of globalisation before 1914. This too seems consistent with the superior performance of the golden age and, to some extent, with the return to higher unemployment after 1973.

Another candidate is the real interest rate. While low interest rates might raise aggregate demand through stimulating investment (which, indeed, was higher during the golden age than previously), this again is a demand side effect. In so far as investment results in capital deepening its effect on real labour demand this should be reflected in faster productivity growth, as already noted. However it has been suggested that, through a variety of 
mechanisms, interest rates might shift the real demand for labour, either by reducing the present value of fixed labour costs, or by stimulating investment to attract or retain customers (Phelps 1994, Phelps and Zoega 1998).

A further elaboration on this general theme is that demand or supply shocks matter more when they interact with labour market institutions that are seen as adverse to employment, some of which are represented by the wage pressure variables described above. Thus, variables that weaken the pressure of high unemployment on wage adjustment tend to magnify the impact of shocks and prolong their effects. One example would be where an increase in the rate of structural change leads to higher and more persistent unemployment the higher is the benefit replacement ratio (Ljungqvist and Sargent 1998). Evidence for OECD countries offers some support for the view that variables such as the benefit replacement ratio, benefit duration, employment protection and union density, when interacted with shocks to employment, help to explain both the differences across countries in the rise of unemployment from the 1970s and its persistence into the 1990s (Blanchard and Wolfers, 2000, Bertola et al. 2001).

The second hypothesis is that the behaviour of the labour market was radically different during the golden age than it was at other times. Perhaps the most persuasive notion is that the 'postwar consensus' engendered cooperation between employers' leaders and trade unions that was absent before the Second World War and that collapsed during the 1970s. Accounts that stress this view see a three-way implicit contract between employers, trade unions and the government. Increasingly centralised trade unions co-ordinated moderation in their wage claims, refraining from using their increased industrial muscle at the national level and restraining militancy at the local and firm levels. In exchange, employers acceded to union control of restrictive practices at the workplace while maintaining high levels of investment. The contract was underpinned by the government, which committed to an expanded welfare state and to using Keynesian-style macroeconomic policies to maintain economic stability.

One variant of this approach emphasises the degree of centralisation in the bargaining structure and the degree of co-ordination in wage bargaining across sectors (Calmfors and Driffill 1988, Soskice 1991). When unions are strong but the bargaining structure is fragmented and unco-ordinated, individual wage bargains do not take into account the economy-wide effects of the bargains independently struck in each sector. This lack of co-ordination is illustrated by Keynes' comment a year before the general strike of i926: 'Our export industries are suffering because they are the first to be asked to accept the 10 per cent [wage] reduction. If every one was accepting a similar reduction at the same time, the cost of living would fall, so that the lower money wage would represent nearly the same real wage as before. But, in fact, there is no machinery for effecting a simultaneous reduction' (Keynes 1931, p. 247). 
This situation can be contrasted with two extremes. With atomistic wage bargaining at the local or firm level, wage bargainers take into account the effect on employment of the high elasticity of demand faced by the individual firm in an industry. Thus potential job losses lead to moderation in wage claims. At the other extreme, when wage setting is co-ordinated through an encompassing institutional wage structure, a wage increase affects all firms equally. But centralised wage setters are more likely to take into account the economy-wide effects of their actions and therefore to co-ordinate on a set of wage bargains that would be consistent with high employment.

It is tempting to associate low unemployment during the golden age with a high level of centralised co-operation in which sectional interests were suppressed. Indeed, a number of influential studies have seen this postwar consensus as a unique phase in British industrial relations (Middlemass 1979, Flanagan et al. 1983, Eichengreen 1996, Eichengreen and Iversen 1999). Table 1 provides evidence that national collective bargaining covered nearly three-quarters of employment during the golden age, with some decline subsequently. But wage bargaining was still very fragmented between and within sectors and it is hard to believe that industrial relations structures were sufficiently different during the golden age, as compared to the periods before and after, to have delivered a quarter-century of low unemployment.

Those studies that stress the influence of the postwar consensus emphasise the shift towards co-operation in the leadership of government, industry and unions within an institutional framework that changed only slowly, rather than changes in the structure itself. ${ }^{2}$ The tripartite agreement that underlay the 1944 White Paper on Employment Policy worked well up to the late 1950 s, but as the spirit of co-operation ebbed the edifice of the corporatist structure was strengthened. These developments included amalgamations among trade unions and among employers' associations, the setting up of the National Economic Development Council (in 1961), the introduction of statutory incomes policy (in 1966), and new industrial relations legislation (in 1969 and 1971). ${ }^{3}$

The system was thrown into crisis as the wave of industrial unrest that had been building since the late 1960s was followed by oil price shocks, a productivity slowdown, and subsequent tightening of macroeconomic policy. While a semblance of co-operation continued through the 1970 s, the corporatist approach was finally (and definitively) buried by the Thatcher government that came to office in 1979. Thus the rise and fall of the

${ }^{2}$ Even this spirit of consensus had its limitations. According to Crouch (1995, p. 236) 'it was the kind of consensus that arises when groups put the avoidance of conflict above the search for agreement'.

${ }^{3}$ Middlemass (1979, p. 425) notes that 'Symptoms of excessive formalism and lack of flexibility began to appear in all parts of the system during the 1960s' and that 'the parties to the triangular system had become formal, professional organizations to a degree unforseen in the 1940s'. 
postwar consensus fits rather well with the profile of unemployment and it is not surprising that the two have been linked. But the evidence is largely circumstantial. To date there has been no quantitative analysis to show that, as a result of the postwar consensus, real wages (and hence unemployment) were lower than they would otherwise have been.

\section{A benchmark model of the labour market}

Here we develop a basic framework within which to examine the effects of wage pressure variables and other determinants of unemployment over the long run (see Hatton 2003). Like most models of this type, it consists of a wage-setting equation and an unemployment equation from which an expression for the Non-Accelerating Inflation Rate of Unemployment (NAIRU) can be derived.

The real wage equation is written, with all variables in natural logs, as:

$$
\mathrm{A}(\mathrm{w}-\mathrm{p})_{\mathrm{t}}=\left(3_{0}+\mathrm{PjA}^{\wedge} \mathrm{t}+\mathrm{P}_{2}\left(7 \mathrm{t}_{\mathrm{t}}-\mathrm{i}-(\mathrm{w}-\mathrm{p})_{\mathrm{t}}-\mathrm{i}\right)-\mathrm{P}_{3} \mathrm{u}_{\mathrm{t}-} !+\mathrm{x}_{\mathrm{t}}\right.
$$

where $w-p i s$ the real wage, it is labour productivity, $u$ is the unemployment rate, and $x$ represents a vector of wage pressure variables, including a stochastic error term. This may be thought of as embodying the components of the feasible wage, as represented by labour productivity, and the target wage as reflected in the negative relationship between lagged unemployment and the real wage. ${ }^{4}$ The dynamics are captured as an error correction mechanism such that the real wage adjusts slowly towards its determinants. In the long run, with the real wage and productivity constant, the real wage is a markup on productivity that depends on unemployment and the wage pressure variables. ${ }^{5}$

The unemployment equation is an inverted (nominal) Phillips curve:

$$
\mathrm{u}_{\mathrm{t}}=\infty+\text { cxiut-! }-\mathrm{oc}_{2} \mathrm{AAp}_{\mathrm{t}}-\mathrm{a}_{3} \mathrm{An}_{\mathrm{t}}-\mathrm{a}_{4}\left(7 \mathrm{i}_{\mathrm{L}} \mathrm{i}-(\mathrm{w}-\mathrm{p})_{\mathrm{t}_{-}:}\right)+\mathrm{z}_{\mathrm{t}}
$$

Where $A A p$ is the change in nominal price inflation and $z$ includes labour demand shift variables as well as a stochastic term. A positive price surprise has a negative effect on unemployment but there is also persistence (or hysteresis), as represented by the lagged dependent variable. The third term implies that productivity growth drives down unemployment in the short run. According to the fourth term, unemployment also depends negatively on the gap between productivity and the real wage lagged one period. This can be thought of as a dynamic labour demand equation where there is a short-run positive relationship between the real wage and the unemployment

\footnotetext{
${ }^{4}$ See Layard et al. (1991) and Nickell (1998) for expositions of this general approach.

${ }^{5}$ Thus, ignoring time subscripts, in the long-run stationary state (setting the As to zero): $\mathrm{w}-\mathrm{p}=71+\left(\mathrm{P}_{0}-\mathrm{P} \mathrm{u}+\mathrm{x}\right) / \mathrm{P}_{2}$.
} 
rate. In the long run, with no inflation surprise and the real wage equal to productivity, unemployment depends purely on the factors in $z$ that shift labour demand. ${ }^{6}$

From equations (i) and (2) the NAIRU can be derived for constant values of the exogenous variables (denoted by $*$ ), but assuming productivity growth at a constant rate $g^{*}$, and setting the inflation surprise $\mathrm{A} A p=0$. This gives the NAIRU as:

$$
\mathrm{u}^{t}=\frac{\infty+o c_{4} \mathrm{p}_{0} / \mathrm{p}_{2}+z^{*}+\mathrm{oc}_{4} x^{*} / \mathrm{p}_{2}-\left[\mathrm{oc}_{3}+o \mathrm{c}_{4}\left(\mathrm{i}-\mathrm{p}_{:}\right) / \mathrm{p}_{2}\right] g^{*}}{\mathrm{i}-\mathrm{a}_{1}+\mathrm{a}_{4} \mathrm{p}_{3} / \mathrm{p}_{2}}
$$

Thus the NAIRU will be affected positively by the wage/price pressure variables $x$ and $z$, and it will be a negative function of the steady-state rate of productivity growth. The effects of these variables on the NAIRU will be greater the longer are the lags in wage and unemployment adjustment (the smaller is $\mathrm{p}_{2}$ and the larger is $\left.\mathrm{o}^{\wedge}\right)$. They will be smaller the bigger the effect of unemployment on wage setting (the greater is $\mathrm{P}_{3}$ ) and of productivity on unemployment (the greater is $\left.\mathrm{oc}_{4}\right)^{7}$

\section{The real wage equation}

Estimates of a real wage adjustment equation based on equation (1) above appear in Table 2. The data period excludes the two World Wars and it also excludes the years 1972 to 1979 . This is the transitional period during which the postwar consensus (if there was one) was breaking down. Rather than pick an arbitrary break somewhere in the 1970s, we examine differences in the structure of wage setting before and after the breakdown. We then explore further below the question of how well the model predicts the rise in unemployment over those years.

The first column of Table 2 is a baseline estimate that is explored more fully in Hatton (2003) and it includes period dummies for the interwar years, the golden age and the post-1979 periods. The coefficient on unemployment is negative as expected for a wage setting function, although it has only borderline significance. Productivity growth and the lagged productivity to real wage ratio are both positive, giving strong support for a partial adjustment mechanism linking the real wage to productivity. The ratio of fuel prices to the GDP deflator was found to influence the real wage only in changes rather than in levels and with a negative coefficient. The relative import price has a negative effect in levels (at least in the baseline model) and the effect is also negative, suggesting that an increase in import prices reduces the real wage in the long run.

\footnotetext{
${ }^{6}$ Again, setting the As to zero and ignoring time subscripts: $u=\left(\mathbf{a}_{0}+\mathrm{z}\right) /\left(\mathrm{i}-\mathbf{a}_{\mathbf{r}}\right)$.

${ }^{7}$ These stated effects for changes in the magnitudes of $\mathbf{a}_{\mathbf{4}}$ and $\mathbf{P}_{\mathbf{2}}$ require that $\left(\mathbf{1}-\mathbf{P}_{\mathbf{~}}\right)(\mathbf{i}-\mathbf{a})>\mathbf{P}_{3} \mathbf{a}_{4}$.
} 
Table 2. Real wage estimates, 1872-1913, 1922-38, 1948-71, 1980-99.

\begin{tabular}{|c|c|c|c|c|}
\hline Dependent variable & $\mathrm{A} \log (\mathrm{W} / \mathrm{P})_{\mathrm{t}}$ & $\mathrm{Alog}(\mathrm{W} / \mathrm{P})_{\mathrm{t}}$ & $\mathrm{Alog}(\mathrm{W} / \mathrm{P})_{\mathrm{t}}$ & $\mathrm{A} \log (\mathrm{W} / \mathrm{P})_{\mathrm{t}}$ \\
\hline Constant & $\begin{array}{l}\mathrm{O} .150 \\
(3-0)\end{array}$ & $\begin{array}{l}0.140 \\
(2.2)\end{array}$ & $\begin{array}{l}0.066 \\
(\mathrm{i}-\mathrm{o})\end{array}$ & $\begin{array}{l}0.035 \\
(4-5)\end{array}$ \\
\hline $\begin{array}{l}\text { Log unemployment } \\
\quad \text { rate }(t-1)\end{array}$ & $\begin{array}{c}-0.009 \\
(i-9)\end{array}$ & $\begin{array}{l}-\mathrm{O} . \mathrm{OII} \\
(2.1)\end{array}$ & $\begin{array}{c}-0.017 \\
(3-3)\end{array}$ & $\begin{array}{c}-0.018 \\
(4.2)\end{array}$ \\
\hline Alog productivity (t) & $\begin{array}{l}0-534 \\
(6.4)\end{array}$ & $\begin{array}{l}\text { O.524 } \\
(6.2)\end{array}$ & $\begin{array}{l}0.461 \\
(5-4)\end{array}$ & $\begin{array}{l}0.461 \\
(5-4)\end{array}$ \\
\hline $\begin{array}{l}\text { Log productivity }(\mathrm{t}-1) \\
-\log \text { real wage }(\mathrm{t}-1)\end{array}$ & $\begin{array}{l}0.407 \\
(6-5)\end{array}$ & $\begin{array}{l}0.397 \\
(5-3)\end{array}$ & $\begin{array}{l}0.340 \\
(4-6)\end{array}$ & $\begin{array}{l}0.297 \\
(5-2)\end{array}$ \\
\hline $\begin{array}{l}\text { Alog relative fuel } \\
\text { price }(\mathrm{t})\end{array}$ & $\begin{array}{c}-0.032 \\
(2.9)\end{array}$ & $\begin{array}{c}-0.033 \\
(\mathbf{3}-\mathbf{0})\end{array}$ & $\begin{array}{c}-0.031 \\
(2.8)\end{array}$ & $\begin{array}{c}-0.030 \\
(2.8)\end{array}$ \\
\hline $\begin{array}{l}\text { Log relative import } \\
\text { price }(\mathrm{t}-1)\end{array}$ & $\begin{array}{c}-0.027 \\
(2.7)\end{array}$ & $\begin{array}{c}-0.025 \\
\text { d-9) }\end{array}$ & $\begin{array}{c}-0.007 \\
(0.5)\end{array}$ & \\
\hline $1922-38$ & $\begin{array}{c}-0.007 \\
(1.2)\end{array}$ & $\begin{array}{l}0.017 \\
(\mathrm{i}-3)\end{array}$ & & \\
\hline $1948-71$ & $\begin{array}{l}0.048 \\
(4-5)\end{array}$ & $\begin{array}{l}0.024 \\
(0.9)\end{array}$ & & \\
\hline $1980-99$ & $\begin{array}{l}0.034 \\
(4-9)\end{array}$ & $\begin{array}{c}0.096 \\
(0.03)\end{array}$ & & \\
\hline Replacement rate $(t-1)$ & & $\begin{array}{l}0.015 \\
(0.5)\end{array}$ & $\begin{array}{l}-0.041 \\
(\mathrm{i}-3)\end{array}$ & \\
\hline ATrade union density ( $t$ ) & & $\begin{array}{l}0.021 \\
(0.2)\end{array}$ & $\begin{array}{l}0.100 \\
(0.7)\end{array}$ & \\
\hline Direct tax share $(\mathrm{t}-1)$ & & $\begin{array}{c}-0.092 \\
(0.7)\end{array}$ & $\begin{array}{l}0.028 \\
(4-i)\end{array}$ & $\begin{array}{l}0.198 \\
(6.0)\end{array}$ \\
\hline $\begin{array}{l}\text { Replacement rate }(\mathrm{t}-1) \\
\quad \mathrm{x} 1948-71\end{array}$ & & & $\begin{array}{l}0.158 \\
(2.9)\end{array}$ & $\begin{array}{l}0.130 \\
(2.7)\end{array}$ \\
\hline $\begin{array}{l}\text { ATrade union density } \\
\text { (t) } x \text { 1948-71 }\end{array}$ & & & $\begin{array}{l}0.506 \\
(\mathrm{i}-7)\end{array}$ & $\begin{array}{l}0.676 \\
(2.6)\end{array}$ \\
\hline $\begin{array}{l}\text { Direct tax share }(\mathrm{t}-1) \\
\quad \mathrm{x} 1948-71\end{array}$ & & & $\begin{array}{l}-0.352 \\
(2.7)\end{array}$ & $\begin{array}{l}-0.330 \\
(2.7)\end{array}$ \\
\hline Adj. $R^{2}$ & 0.48 & 0.47 & 0.45 & 0.45 \\
\hline D.W. & 1.67 & 1.72 & 1.77 & 1.80 \\
\hline RESET & 4.12 & 8.46 & 1.37 & 0.78 \\
\hline HETERO & 1.94 & 1.62 & 1.31 & 0.45 \\
\hline
\end{tabular}

Notes: ' $\mathrm{t}$ ' statistics in parentheses. RESET is the functional form test using the powers of the fitted values, distributed as $\left.\mathrm{F}_{3 \mathrm{jn} \_\mathrm{k}}\right)$. HETERO is the test for heteroskedasticity using the fitted values, distributed as $/ \mathbf{L}$

More notable is the effect of the period dummies, which are positive and significant for the golden age and post-1979. Contrary to what might be expected from the literature on the postwar consensus, the real wage was not lower during the golden age than at other times, once labour productivity and 
unemployment are taken into account. Whatever else the postwar consensus may have done, it did not reduce average unemployment by reducing the real wage relative to productivity. However, this estimate does not include wage pressure variables and it is possible that, once these are taken into account, a negative wage effect might emerge during the golden age. This is tested in column (2) where three additional variables are added. The first is the benefit replacement rate adjusted to allow for the changing coverage of benefit systems, and lagged one period. This produces a coefficient that is positive but small and highly insignificant. The second additional variable is trade union density, a variable usually thought to represent the strength of trade unions in wage bargaining. This is included as the change rather than as the level, which would be consistent with the idea that trade unions exert leverage chiefly during periods of expansion. Here the coefficient is positive as expected but again it is small and insignificant. The third additional variable is the direct tax wedge, which is negative and also insignificant.

The inclusion of the wage pressure variables in column (2) reduces the period dummies to insignificance but it does not support the idea that these variables had much influence over the period as a whole. It could be, however, that these variables had different effects during the golden age than they did in other periods. Accordingly, in column (3) the period dummies are eliminated but the wage pressure variables are interacted with the dummy variable for the period 1948-71. The result indicates that the replacement rate and trade union growth exerted more influence during the golden age than at other times, and not less, as a casual reading of the literature on the postwar consensus might suggest. But it is consistent with Broadberry (1994) who also finds that these variables had larger effects after the Second World War than they did during the interwar period. However it is something of a surprise to find that the replacement rate and unionism had no discernible effects before and after the golden age. That finding is not overturned when union density is included as a level, or when different lags are used, or when the pre-1914 period is excluded.

The pattern of coefficients of the more parsimonious specification in column (4) suggests a rather different interpretation of labour market structure during the golden age. As is often noted, moderation in national wage bargaining was largely undone by vigorous and sometimes militant activity led by shop stewards at the firm and local level. As a result, national wage bargains were topped up by wage supplements negotiated at the plant and firm level, such that earnings persistently increased faster than national wage rates - a process that became known as 'wage drift'. ${ }^{8}$ The bargaining strength of shop stewards is likely to have depended more on strength of numbers than did national negotiations, and they are likely to 
have been more responsive to the level of support for members who lost their jobs.

Equally notable are the coefficients on the share of direct tax in national income. These indicate that before and after the golden age, the tax wedge tended to increase the real wage. ${ }^{9}$ By contrast, during the golden age that seemingly strong effect disappeared and was even slightly reversed. Insofar as increases in the tax share reflected the expansion of the welfare state, this did not add to wage pressure during the golden age. Thus the impact of the postwar consensus on the wage bargain appears to be the following. Before and after the golden age workers' bargaining power was weak and the target wage was the private wage; during the golden age bargaining power was stronger but the target wage was the social wage. These two forces operated in opposite directions with the result that, relative to the economic fundamentals, the real wage was no lower during the golden age than it was at other times.

\section{The unemployment equation}

Estimates of the equation for unemployment, based on equation (2) above appear in Table 3. Again, the baseline specification in the first column is explored more fully in Hatton (2003). This version includes two lags of the dependent variable reflecting the dynamics of employment adjustment. The change in inflation (the Phillips curve term) reflecting the price surprise is significantly negative as expected. Productivity growth and the lagged productivity to real wage ratio are also negative, the latter supporting the view that the higher is the real wage relative to productivity the higher is unemployment. The relative fuel price is positively related to unemployment (as a level rather than as a change) even though the oil shocks of the 1970s are excluded. Of the three period dummies, the most important is that for the golden age which gives a large negative coefficient. This is not surprising since, as was noted earlier, the postwar consensus did not generate real wages that were lower than at other times. Hence the unusually low unemployment in the golden age must be accounted for by other variables - in this case the period dummy.

The second column of Table 3 adds three additional variables that might help to explain shifts in the average unemployment rate that are accounted for by the period dummies in the first column. The real interest rate is significantly positive, supporting the view that it works through channels other than investment and capital deepening (since labour productivity is already taken into account). The growth in the volume of world trade (a proxy

\footnotetext{
${ }^{9}$ This finding is consistent with the Thatcher government's sudden shift from direct to indirect taxes in the 1980 budget and with the establishment of a new tax-and-price index to represent changes in the cost of living.
} 
Table 3. Unemployment rate estimates, 1872-1913, 1922-38, 1948-71, 1980-99.

\begin{tabular}{|c|c|c|c|c|}
\hline Dependent variable & $\log \mathrm{U}_{\mathrm{t}}$ & $\log U_{t}$ & $\log \mathrm{U}_{\mathrm{t}}$ & $\log \mathrm{U}_{\mathrm{t}}$ \\
\hline Constant & $\begin{array}{l}-0.390 \\
(0.5)\end{array}$ & $\begin{array}{c}-0-397 \\
(0.5)\end{array}$ & $\begin{array}{l}-0.306 \\
(0.4)\end{array}$ & $\begin{array}{l}-0.378 \\
(i-3)\end{array}$ \\
\hline $\begin{array}{l}\text { Log unemployment } \\
\text { rate }(t-1)\end{array}$ & $\begin{array}{l}0.841 \\
(9-6)\end{array}$ & $\begin{array}{l}0.950 \\
(10.9)\end{array}$ & $\begin{array}{l}0.966 \\
(10.9)\end{array}$ & $\begin{array}{l}0.935 \\
(2.6)\end{array}$ \\
\hline $\begin{array}{l}\text { Log unemployment } \\
\text { rate }(t-2)\end{array}$ & $\begin{array}{c}-0.097 \\
(1.1)\end{array}$ & $\begin{array}{l}-0.246 \\
(2.8)\end{array}$ & $\begin{array}{l}-0.240 \\
(2.6)\end{array}$ & $\begin{array}{l}-0.204 \\
(2.6)\end{array}$ \\
\hline AAlog price level (t) & $\begin{array}{l}-1.790 \\
(2.4)\end{array}$ & $\begin{array}{c}-2.387 \\
(3-4)\end{array}$ & $\begin{array}{l}-2-477 \\
(3-5)\end{array}$ & $\begin{array}{c}-2.530 \\
(3-7)\end{array}$ \\
\hline Alog productivity (t) & $\begin{array}{l}-3.229 \\
(2.4)\end{array}$ & $\begin{array}{l}-2.946 \\
(2.6)\end{array}$ & $\begin{array}{l}-2.323 \\
(\mathrm{i}-9)\end{array}$ & $\begin{array}{l}-2.967 \\
(2.6)\end{array}$ \\
\hline $\begin{array}{l}\text { Log productivity }(\mathrm{t}-1) \\
-\log \text { real wage }(\mathrm{t}-1)\end{array}$ & $\begin{array}{l}-2.065 \\
(2.1)\end{array}$ & $\begin{array}{c}-2.037 \\
(3-9)\end{array}$ & $\begin{array}{c}-1-355 \\
(14)\end{array}$ & $\begin{array}{c}-2.119 \\
(2.6)\end{array}$ \\
\hline Log relative fuel price $(t-1)$ & $\begin{array}{l}0.187 \\
(2.4)\end{array}$ & $\begin{array}{l}0.176 \\
(2.5)\end{array}$ & $\begin{array}{l}0.152 \\
(2.0)\end{array}$ & $\begin{array}{l}0.198 \\
(2.9)\end{array}$ \\
\hline $\begin{array}{l}\text { Log relative import } \\
\text { price }(\mathrm{t}-1)\end{array}$ & $\begin{array}{l}0.012 \\
(0.1)\end{array}$ & $\begin{array}{l}0.041 \\
(0.3)\end{array}$ & $\begin{array}{l}0.032 \\
(0.2)\end{array}$ & \\
\hline $1922-38$ & $\begin{array}{l}0.104 \\
(1.2)\end{array}$ & $\begin{array}{l}0.106 \\
(1.2)\end{array}$ & $\begin{array}{l}0.097 \\
(1.0)\end{array}$ & \\
\hline $1948-71$ & $\begin{array}{c}-0.687 \\
(4-i)\end{array}$ & $\begin{array}{l}-0.642 \\
(4.2)\end{array}$ & $\begin{array}{c}-0.307 \\
(1.2)\end{array}$ & $\begin{array}{c}-0.652 \\
(4-3)\end{array}$ \\
\hline $1980-99$ & $\begin{array}{l}-0.231 \\
\mathbf{d}-\mathbf{5})\end{array}$ & $\begin{array}{c}-0.173 \\
(1.2)\end{array}$ & $\begin{array}{c}-0.105 \\
(0.7)\end{array}$ & $\begin{array}{l}-0.258 \\
(2.1)\end{array}$ \\
\hline Real interest rate $(\mathrm{t}-1)$ & & $\begin{array}{l}1.817 \\
(3-3)\end{array}$ & $\begin{array}{l}1.628 \\
(2.7)\end{array}$ & $\begin{array}{l}1.919 \\
(3-6)\end{array}$ \\
\hline Alog world trade $(t)$ & & $\begin{array}{c}-0.952 \\
(2.5)\end{array}$ & $\begin{array}{c}-0.874 \\
(2.2)\end{array}$ & $\begin{array}{c}-1.122 \\
(3-2)\end{array}$ \\
\hline $\begin{array}{l}\text { Structural change } \\
\text { index }(t)\end{array}$ & & $\begin{array}{l}-0.020 \\
(1.2)\end{array}$ & $\begin{array}{c}-0.013 \\
(1.0)\end{array}$ & \\
\hline $\begin{array}{l}\text { Real interest rate } \\
\qquad(\mathrm{t}-1) \times 1948-71\end{array}$ & & & $\begin{array}{l}0.646 \\
(0.4)\end{array}$ & \\
\hline $\begin{array}{l}\text { Alog world trade } \\
\text { (t) } \times 1948-71\end{array}$ & & & $\begin{array}{l}-1.362 \\
(1.2)\end{array}$ & \\
\hline $\begin{array}{l}\text { Structural change } \\
\text { (t) } \times 1948-71\end{array}$ & & & $\begin{array}{l}-0.056 \\
(1.0)\end{array}$ & \\
\hline $\operatorname{Adj} . \mathrm{R}^{2}$ & 0.94 & 0.95 & 0.95 & 0.95 \\
\hline D.W. & 1.48 & 1.78 & I.73 & 1.74 \\
\hline RESET & 1.64 & 1.13 & 0.95 & 2.75 \\
\hline HETERO & 1.49 & 5.91 & $5-95$ & 3.48 \\
\hline
\end{tabular}

Notes: 't' statistics in parentheses. RESET is the functional form test using the powers of the fitted values, distributed as $\mathrm{F}^{\wedge} \wedge^{\wedge}$. HETERO is the test for heteroskedasticity using the fitted values, distributed as $\mathbf{X M} \bullet$ 
for exogenous demand shocks) is negative as expected, also with a sizeable coefficient. The third additional variable is our index of short-run structural change. Contrary to expectation, this turns out to be negative but not significant and hence differences in the pace of structural change contribute very little to explaining medium- and long-term shifts in the average unemployment rate. Nevertheless, two out of three additional variables matter, and in their presence several of the other coefficients become more significant. But they fail to drive away the large negative coefficient on the period dummy for the golden age.

The third column of Table 3 examines the hypothesis that the three additional variables had different effects during the golden age than at other times. The result of adding interactions with the 1948-71 dummy suggests that they did not. Although some of the interacted coefficients are large they are not individually significant and the coefficients on the un-interacted variables are little changed. The fourth column offers a more parsimonious specification in which just two period dummies appear. These indicate that, conditioning on other variables, there was a large outward shift in real labour demand during the golden age that was partially reversed in the 1980s. For given values of the real wage, productivity, and other relevant variables, employment was higher and unemployment was lower between 1948 and 1971 than it was during the other major eras. Precisely how and why this occurred remains unclear.

\section{Calculating the NAIRU}

One way of assessing the contribution of different variables to the average unemployment rate across these periods is to calculate the NAIRU for each period using the empirical counterpart to equation (3) above. Here, the price surprise in the unemployment equation is set to zero and the NAIRU is calculated by setting all the other variables at their period means. The values of the NAIRU presented in Table 4 are based on the estimated wage equation in the fourth column of Table 2 and the estimated unemployment equation in the fourth column of Table 3. The first row of Table 4 is the observed average unemployment rate over each of the periods while the second row is the calculated value of the NAIRU. Not surprisingly the NAIRU is fairly close to the observed average unemployment rate for each period, although it is a little lower than the average for the interwar period and for the post-1979 period.

In the next four rows the NAIRU is calculated holding one of the variables constant at its average over the whole period 1872-1913, 1922-38, 194871 and 1980-99. The comparison between the entries in row (2) and the following rows isolates the contribution of each of these variables to the cross-period differences in the NAIRU. Row (3) holds productivity growth 
Table 4. Estimates of the NAIRU for different periods.

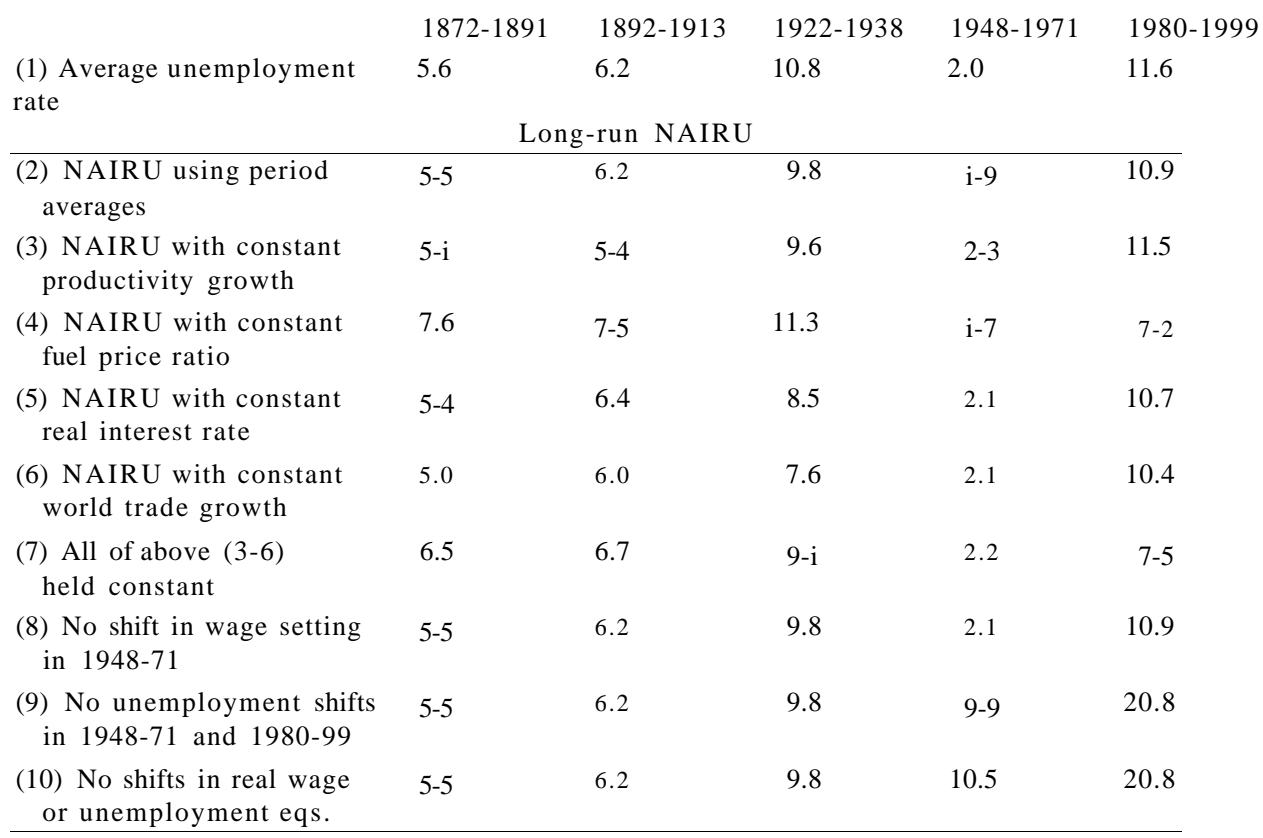

constant at the whole period average (1.54 per cent per annum). Belowaverage productivity growth in the pre-1914 period added modestly to the NAIRU, especially from the 1890 s to 1913 . And above-average productivity growth reduced unemployment during the golden age, but only by 0.4 percentage points. In row (4), the real fuel price is held constant (at 122.6; $1913=$ 100). Below-average real fuel prices reduced the NAIRU in the periods before the Second World War, particularly in 1872-91. But the sharp rise in relative fuel prices across the Second World War, and again in the 1970s, raised the NAIRU - by 3.7 percentage points in the period after 1979 .

Although the real interest rate has powerful effects in the unemployment equation its impact on the NAIRU across major periods is modest (row 5). At the whole period average real interest rate ( 3.22 per cent) the NAIRU would have been lower by 1.3 percentage points in the interwar period and a shade higher during the golden age. The effects of the growth of world trade are also surprisingly modest (row 6). With world trade growth at its whole period mean (4.31 per cent) the NAIRU for the interwar period would have been two percentage points lower than it was and that for the golden age would have been only a shade higher. With all four of these variables simultaneously held at their whole-period means as in row (7), the overall pattern of relative unemployment rates between periods is largely preserved. Together these forces raised the NAIRU slightly in the interwar period, lowered it slightly in the postwar period, and raised it more substantially in the post-1979 period. 
What were the effects of shifts in the wage setting and unemployment equations during the golden age? In row (8) the coefficients of the wage equation before and after the golden age are applied to the period 194871 as well. In this period the NAIRU would have been a shade higher in the absence of the shifts in wage setting that characterised the postwar consensus. This is largely because of the reversal of the effects of the direct tax wedge during the golden age. Thus the postwar consensus, as it applied to wage setting, did reduce unemployment slightly. However, the lower NAIRU during the golden age is mostly accounted for by the period dummies in the unemployment equation. Row (9) gives values of the NAIRU eliminating the dummies for 1948-71 and 1980-99. This raises the NAIRU to 9.9 per cent for the golden age and to more than 20 per cent for the 1980s and 1990s.

\section{What happened in the 1970s?}

The dramatic fall in the unemployment rate across the Second World War seems to have been largely due to a shift in labour demand that cannot be accounted for by the economic variables that appear in the model. Specifically: for a given ratio of the real wage relative to productivity, unemployment was lower than ever before or since. As reflected in the changing structure of the wage equation, the postwar consensus had only modest effects in reducing unemployment. The turbulent decade of the 1970s is often seen as a watershed between the low unemployment era of the golden age and the return to high equilibrium unemployment more characteristic of the interwar period. That much is clear, but it is much less clear exactly what accounted for the upward drift in unemployment over the decade. Here we investigate three possibilities: the breakdown of the postwar consensus, negative shocks emerging from the world economy, and the reversal of the favourable shifts in labour demand that took place across the Second World War.

Table 5 reports the results of a series of simulations for the period 1972 to 1979. The first row shows the actual unemployment rate. After rising to 4 per cent in 1972, unemployment fell to 2.8 per cent and then rose again to reach 6.1 per cent in 1977. The second row is the result of a recursive simulation that uses the real wage equation in the last column of Table 2 and the unemployment equation in the last column of Table 3 . The coefficients used are those for the golden age (that is, setting the dummy for 1948-71 equal to one). The simulation starts from the actual value of the real wage for 1971 and the actual values of the unemployment rate for 1970 and 1971. Thereafter the values predicted by the model are used as lagged values for subsequent years. The unemployment rates that emerge from the simulation are a shade lower than the actuals in the early 1970s and the gap increases through the late 1970s. Thus more than half of the increase in unemployment 
Table 5. Counterfactual unemployment in the 7970s.

\begin{tabular}{lllllllll}
\hline Ye a r & 1972 & 1973 & 1974 & 1975 & 1976 & 1977 & 1978 & 1979 \\
\hline $\begin{array}{l}\text { (1) Actual unemployment } \\
\text { rate }\end{array}$ & 4.0 & 2.8 & 2.8 & $4-3$ & 5.8 & 6.1 & 6.0 & 5.6 \\
$\begin{array}{l}\text { (2) Simulated } \\
\text { unemployment rate }\end{array}$ & 3.6 & 2.7 & 2.3 & 2.8 & $3-9$ & 3.8 & 4.0 & 4.0 \\
$\begin{array}{l}\text { (3) No postwar consensus } \\
\text { (4) No inflation shocks, }\end{array}$ & 3.6 & 2.7 & 2.3 & 2.6 & 3.6 & $3-5$ & $3-7$ & $3-7$ \\
$\quad$ post-1971 & 2.6 & 2.7 & 4.0 & 4.1 & 34 & $3-5$ & 3.8 \\
$\begin{array}{l}\text { (5) No real interest rate } \\
\text { decline, post-1971 }\end{array}$ & $3-7$ & 2.8 & 2.5 & 3.0 & 4.2 & 4.1 & $4-3$ & $4-3$ \\
$\begin{array}{l}\text { (6) No real fuel price } \\
\text { increase, post-1971 }\end{array}$ & 34 & 2.6 & 2.2 & 2.5 & $3-3$ & $3-i$ & $3-i$ & $3-i$ \\
(7) No productivity \\
$\quad$ slowdown, post-1973
\end{tabular}

between 1973 and 1979 is due to shocks or shifts that are not accounted for by the simulation.

Row (3) reports the result of a similar simulation, but this time the interactions in the wage equation between the dummy for 1948-71 and the direct tax share, the replacement rate, and trade union density, are removed. This simulation asks what the unemployment rate would have been if the postwar consensus had broken down in 1972 rather than continuing through the 1970s. This result should be compared with the simulation in the second row. It suggests that in the absence of the postwar consensus the unemployment rate would have been the same until 1975. After that, unemployment is 0.3 percentage points lower in the absence of the postwar consensus than when the wage equation relevant to 1948-71 is used. This suggests that the breakdown of the golden age wage-setting structure was not the cause of rising unemployment during the 1970s. If anything it was the opposite; real wages and unemployment would have been slightly higher at the end of the 1970s under the golden age wage-setting regime.

The 1970s saw a series of other shocks that affected unemployment, some positive and some negative. The burst of inflation that peaked in 1975 should have helped keep unemployment down, at least until the mid-1970s. Row (4) of the Table shows the result of a simulation where, from 1972, the inflation rate is held constant (so that the change in inflation is zero). Not surprisingly, the simulated unemployment rate is higher than in row (2) in 
the mid 1970s when inflation was on the rise, especially at the peak of 1975, and a little lower in the late 1970s as the inflation rate was falling. Another factor that should have been keeping unemployment down is the real interest rate. In the years of high inflation real interest rates were lower even than the low rates that characterised most of the golden age. From 1972 to 1979 the real ex ante long-term interest rate lagged one period was close to zero, as compared to an average rate for 1948-71 of 1.3 per cent. The simulation in row (5) assumes that, in each year from 1972, the real interest rate is higher than its actual value by 1.3 percentage points. As compared with the simulation in row (2) unemployment is higher by an amount that increases from 0.1 percentage points in 1972 to 0.3 percentage points in 1976-79. Thus the effects of unanticipated inflation and low real interest rates held unemployment down during the 1970s, but only modestly.

However, there were several other variables that were acting in the opposite direction. The increase in real oil prices, the productivity slowdown and the slowdown in the growth of world trade are often identified as having contributed to the rise in unemployment over the 1970s. The simulations in rows (6) through (8) examine the contributions of each of these in turn. $\mathrm{Had}$ the real fuel price remained at its 1971 level in subsequent years (row 6), unemployment would have been lower by 0.9 percentage points by 1979 . Similarly, productivity growth was slower by 1.34 per cent in 1974-79 than it had been in the years up to 1973 . Raising productivity growth by 1.34 per cent after 1973, as in row (7), also cuts unemployment by -0.8 percentage points by 1979 . And had the growth of world trade not fallen by 2.3 percentage points after 1971 the unemployment rate would have been lower, but only by 0.3 percentage points in 1979 .

Row (9) shows the simulated result of all three of these effects taken together. It clearly implies that negative shocks were important in the 1970s. In their absence, the predicted unemployment rate would not have increased at all between 1972 and 1979 whereas the simulation in row (2) indicates a rise from 2.7 per cent to 4.0 per cent. But the actual unemployment rate rose by more than this. How much of that additional increase was due to shifts in the structure of the wage and unemployment equations can be seen in Figure 2. The Figure compares two simulations that begin in 1972. One uses the 1948-71 coefficients while the other uses the coefficients estimated for 1980-99. Under the golden age regime unemployment rises to a peak of 5.3 per cent in 1981 and then begins to decline. By contrast, had the change to the post-1980 regime taken place in 1972, unemployment would have soared in the mid-1970s by much more than it did. The actual unemployment rate exhibits a transition between the two regimes during the 1970s, with the sharpest rise occurring from $1980 .{ }^{10}$ Thus, while there was

${ }^{10}$ The further rise in unemployment after 1980 might be taken to suggest that the data period used in estimation for the post-postwar consensus period should have started 


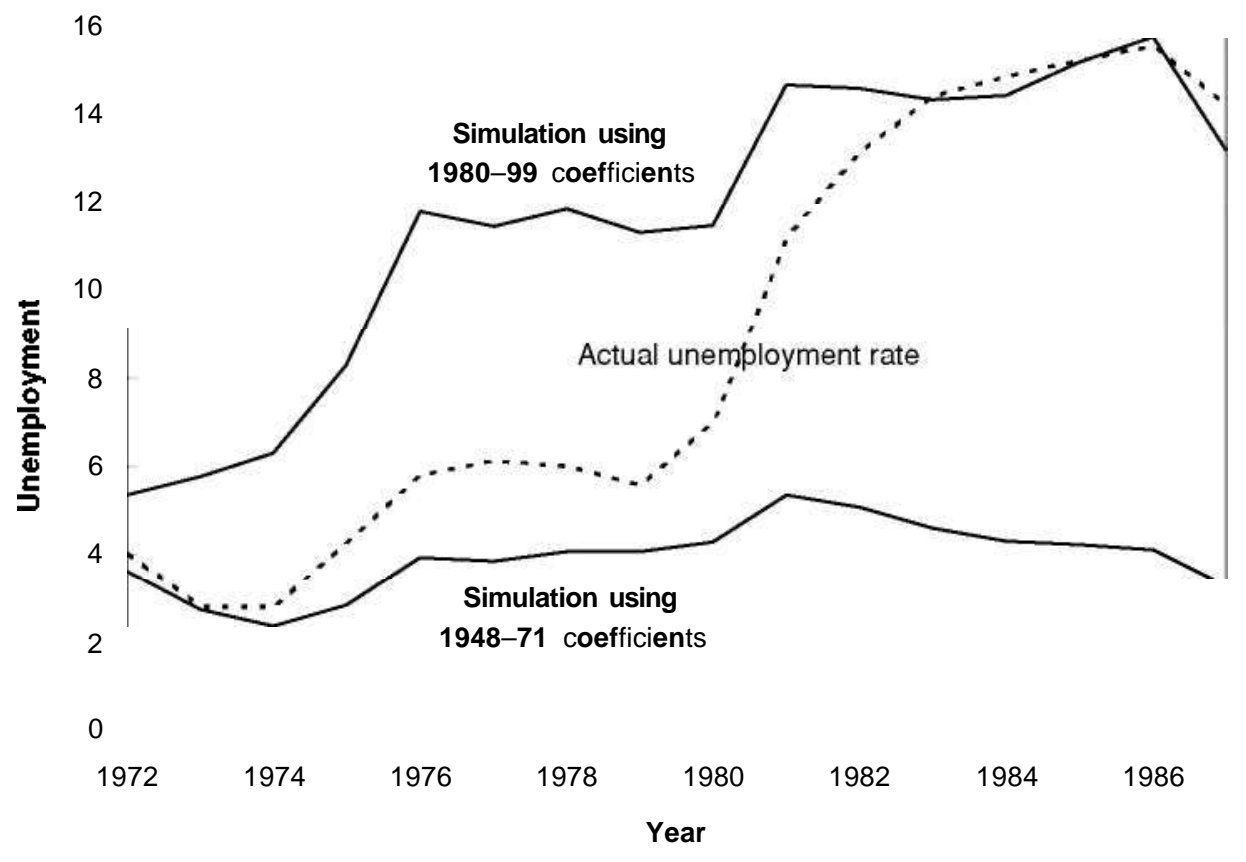

Figure 2. Unemployment, simulated and actual.

a gradual regime shift in the 1970s, the more decisive shift was from 1980 onwards.

\section{Conclusion}

A number of conclusions emerge from our study of unemployment during the golden age as compared with the periods before and after. They can be summarised as follows:

- Low unemployment during the golden age was not the result of real wages that were set lower relative to productivity than they were in the eras that came before or after.

- If there was a change in the structure of wage setting in the golden age, it seems to have cut in both directions. Upward wage pressure from unemployment benefits and trade unionism was stronger than at other

sometime after 1980. But the dynamics of the wage and unemployment equations are such that the effect of an intercept shift in the unemployment equation cumulates over the following years. This is clearly demonstrated in the simulation where the intercept shift is assumed to have occurred in 1972 . 
times, but the negative effect of the tax wedge disappeared. Thus the postwar consensus seems to have involved bargaining over the social wage.

- Faster growth in productivity and in world trade, coupled with lower real interest rates than was typical of other economic eras, helped keep unemployment low during the golden age, but these effects were small overall.

- The major reason for the low unemployment of the golden age appears to have been an outward shift in the labour demand curve, a shift that was largely reversed from the 1970s.

- The return to higher unemployment in the 1970 s was not due to a change in wage-setting behaviour that might be associated with the demise of the postwar consensus. It was partly due to adverse economic conditions and partly due to labour demand shifts.

- The progressive shift in labour demand began in the early 1970s but the decisive change came in 1980.

The shifts in labour demand remain something of a mystery and it is fair to say that if explaining low unemployment in the golden age is the holy grail, it has not yet been found. Recent studies of unemployment across the OECD see these shifts as associated with the sharp decline in labour's share of national income, which has occurred in a number of countries since the 1970s. Thus Blanchard and Wolfers (2000) find that a fall in the wage relative to the marginal product of labour (a decline in labour's share) is associated with high unemployment because it reflects these adverse demand shifts. And Blanchard and Giavazzi (2003) suggest that this maybe associated with more vigorous deregulation of the labour market than of the product market - reducing labour's rents relative to those on capital, and on balance reducing employment.

While this seems a promising line for further empirical enquiry, there are reasons to be sceptical. First, in the UK, labour's share did not decline in the 1980s and 1990s as it did in other European countries and yet unemployment rose just the same. Second, the estimates of the unemployment equation presented above link higher unemployment with a higher share going to labour (as represented by the ratio of the real wage to productivity), rather than with a lower share - and this seems to be a robust relationship over more than a century. Third, the estimates presented here indicate that it is shifts in the level of unemployment for a given ratio of the real wage to productivity (or for a given share of labour in income) across major economic eras that needs to be explained. This suggests that future research should focus on the unemployment equation rather than on the wage-setting equation. And it would be useful to analyse long-run data for a wider range of countries in order to gain a better understanding of what lies behind these infrequent shifts in labour demand. 


\section{References}

BALL, L. and MANKIW, N. G. (2002). The N A I R U in theory and practice. Journal of Economic Perspectives 16, pp. 115-36.

BALL, L. and MOFFITT, R. (2001). Productivity growth and the Phillips curve. In A. B. Krueger and R. Solow (eds), The Roaring Nineties: Can Full Employment be Sustained? New York: Russel Sage Foundation.

BENJAMIN, D. K. and KOCHIN, L. A. (1979). Searching for an explanation of unemployment in interwar Britain. Journal of Political Economy 87, pp. 441-78.

BERTOLA, G., BLAU, F. D. and KAHN, L. (2001). Comparative analysis of employment outcomes: lessons for the US from international labor market evidence. In A. Krueger and R. Solow (eds), The Roaring Nineties: Can Full Employment be Sustained? New York: Russell Sage Foundation.

BlANCHI, M. and ZOEGA, G. (1997). Challenges facing the natural rate theory. European Economic Review 41, pp. 535-47.

BLANCHARD, O. and GIAVAZZI, F. (2003). Macroeconomic effects of regulation and deregulation in goods and labor markets. Quarterly Journal of Economics 118, pp. 879-907.

BLANCHARD, O. and WOLFERS, J. (2000). The role of shocks and institutions in the rise of European unemployment: the aggregate evidence. Economic Journal HO, pp. C $1-\mathrm{C} 33$.

B OOTH, A. E. and GLYNN, S. (1975). Unemployment in the interwar period: a multiple problem. Journal of Contemporary History 10, pp. 611-37.

BROADBERRY, S. N. (1990). The emergence of mass unemployment: explaining macroeconomic trends in Britain during the trans-World War I period. Economic History Review 43, pp. 272-82.

BROADBERRY, S. N. (1994). Why was unemployment in postwar Britain so low? Bulletin of Economic Research 46, pp. 241-61.

BRUNO, M. and SACHS, J. D. (1985). The Economics of Worldwide Stagflation. Oxford: Blackwell.

CALMFORS, L. and DRIFFILL, J. (1988). Bargaining structure, corporatism and macroeconomic performance. Economic Policy 6, pp. 13-61.

CROUCH, C. (1995). The state: economic management and incomes policy. In P. Edwards (ed.), Industrial Relations: Theory and Practice in Britain. Oxford: Blackwell.

ElCHENGREEN, B. J. (1996). Institutions and economic growth: Europe after World War II. In N. F. R. Crafts and G. Toniolo (eds), Economic Growth in Europe after 1945. Cambridge: Cambridge University Press.

ElCHENGREEN, B. J. and IVERSEN, T (1999). Institutions and economic performance: evidence from the labour market. Oxford Review of Economic Policy 15, pp. 121-38.

FAlliCK, J. L. and Elliot, R. F. (eds) (1981). Incomes Policies, Inflation and Relative Pay. London: Allen and Unwin.

FLANAGAN, R. J., SOSKICE, D. W and ULMAN, L. (1983). Unionism, Economic Stability and Incomes Policies: The European Experience. Washington: Brookings Institution.

HATTON, T J. (1988). Institutional change and wage rigidity in the U K, 1880-1985. Oxford Review of Economic Policy 4, pp. 74-86. 
HATTON, T. J. (2003). Can productivity growth explain the N A IR U ? Evidence from the U K, 1879-1999. Unpublished paper.

KEYNES, J. M. (1931). Essays in Persuasion. London: Macmillan.

LAYARD, P. R. G. and NICKELL, S. J. (1985). The causes of British unemployment. National Institute Economic Review ill, pp. 62-85.

LAYARD, P. R. G., NICKELL, S. J. and JACKMAN, R . (1991). Unemployment, Macroeconomic Performance and the Labour Market. Oxford: Oxford University Press.

LjUNGQVIST, L. and SARGENT, T. J. (1998). The European unemployment dilemma. Journal of Political Economy 106, pp. 514-50.

MATTHEWS, R. C. O. (1968). Why has Britain had full employment since the war? Economic Journal 78, pp. 555-69.

MATthews, R. C. O., FEInstein, C. H. and odling-SMEe, J. C. (1982). British

Economic Growth, 1856-1973. Cambridge: Cambridge University Press.

METCALF, D., NICKELL, S. J. and FLOROS, N . (1982). Still searching for an explanation of unemployment in interwar Britain. Journal of Political Economy 90, pp. 368-99. 96.

MIDDLEMAS S K. (1979). Politics in Industrial Society. London: Andre Deutsch.

MINFORD, P. (1983). Unemployment: Cause and Cure. Oxford: Martin Robertson.

N1CKELL, S. J. (1998). Unemployment: questions and some answers. Economic Journal 108, pp. 802-16.

PHELPS, E. S. (1994). Structural Slumps. Cambridge M A : Harvard University Press.

PHELPS, E. S . and ZOEGA, G. (1998). Natural rate theory and O E C D unemployment. Economic Journal 108, pp. 782-801.

SOS KICE, D. (1991). Wage determination: the changing role of institutions in advanced industrialized countries. Oxford Review of Economic Policy 6, pp. 36-61.

\section{Appendix}

\section{Data Sources}

Unemployment rate. Number unemployed divided by the labour force, based on postwar definitions from Boyer and Hatton (2002), Appendix Table A2, p. 31. 1920-1999: number unemployed based on unemployment insurance and claimant count measures, adjusted for changes in eligibility conditions in the 1980s, and divided by the labour force (below); 1870-1914, based on trade union data and other sources, adjusted to the insurance-based estimates for unionised sectors for the interwar period and then adjusted to the whole economy using the relationship between unemployment in the sectors covered for the nineteenth century and the aggregate unemployment rate estimated for 1923-39 and 1948-71.

Labour force. Unemployed plus employed wage and salary earners. 1920-1999: unemployed plus employed wage earners (workforce jobs) derived in Boyer and Hatton (2002); 1870-1913: working population net of the armed forces from Feinstein (1972), Table 57, pp. T125-6, adjusted to exclude employers and the self-employed. 
Price index. Implicit deflator for GDP at factor cost. 1870-1965: Feinstein (1972), Table 61, pp. T132-3; 1966-90: Office of National Statistics, Economic Trends, Annual Supplement (2000), Table 1.1, p. 7.

Wage rates. Nominal earnings for full-time manual employees. 1870-1990: Feinstein (1995), Table A.24, pp. 263-6; 1990-99: Labour Force Trends (2000), Table 3.2, p. 40.

Replacement rate. Unemployment benefit for an adult male supporting a wife and two children (excluding housing and other benefits) relative to average full-time earnings. 1870-1913: median benefit rate for trade union members covered by benefit schemes (set at 10s throughout), based on Southall (1998), Table 3, p. 23; Royal Commission on Labour (1892), vol. 36; Board of Trade (1912), pp. 1xxvi-lxxvii; 1920-50: benefit rates from Burns (1941), Table 11, p. 368; wage rate 1870-1950, from Feinstein (1995), as above; 1951-72: replacement rate from Metcalf et al. (1980), Table 1, pp. 4-5; 1973-99: replacement rate from an unpublished Bank of England memorandum (by H. Bakhshi).

Proportion eligible for unemployment benefit. 1870-1913: constructed from various Board of Trade sources that list the membership of unions that paid benefit; 1920-48: insured population from Department of Employment (1971), pp. 210-29, 312-3, divided by the labour force (above) and set at 1 from the advent of universal unemployment insurance in 1948 onwards.

Trade union density. Trade union membership as a proportion of the labour force. 1892-1977: Bain and Price (1980), Table 2.1, p. 37; 1978-99: Department of Trade and Industry 〈http://www.dti.gov.uk/er/mar/trade.tables.pdf >, divided by the labour force (above). For 1870-1892 trade union density from Raehsler (1993), Appendix A, pp. 192-3, spliced to the above series at 1892 .

Coverage of national agreements. Coverage of national agreements on collective pay setting including statutory Trade Boards and Wage Councils. Calculated (as midpoint of range, benchmark estimates) from Milner (1994), Table 3. Pre-1974 figures are from changes-in-pay-rates data, post-1973 from Workplace Industrial Relations survey data.

Direct tax share. Income tax and National Insurance contributions (excluding taxes on capital and property) divided by nominal GDP. 1870-1965: Feinstein (1972), Table 14, p. T35; 1966-99: Economic Trends Annual Supplement (2000), Table 5.4, p. 245. Nominal GDP at factor cost (income estimate), 1870-1965: Feinstein (1972), Table I, p. T35; 1966-1999: Economic Trends Annual Supplement (2000), Table 1.2, p. 11.

Import price/GDP deflator. Import unit value index. 1870-1965: Feinstein (1972), Table 64, p. T139; 1966-99: Economic Trends Annual Supplement (2000), Table 1.21, p. 131. GDP deflator, 1870-1999, as above.

Fuel price index/GDP deflator. 1870-1946: pithead price of coal from Church (1986), Table 1.9, p. 54, and Supple (1987), Table 1.1, p. 8; crude petroleum import price, 1921-46 from Jenkins (1986), Table 4, p. 6; 1946-99: price per ton of coal and of heavy fuel oil from Jenkins (1986), Table 71, p. 73, and Department of Trade and Industry (2000) Table 9.13. Coal and oil price index calculated for 19201999 using weights derived from Jenkins (1986), Table 119, p. 133 and Department of Trade and Industry (2000), Table 1.9, p. 34. GDP deflator, 1870-1999, as above. 
Labour productivity. GDP per employed worker. 1870-1965: Feinstein (1972), Table 20, p. T51; 1966-1999: Economic Trends Annual Supplement (2000), Table 3.8, p. 172 .

Structural change index. Defined as $\mathrm{S}_{\mathrm{t}}=£ ; \mathrm{w} ;\left|\mathrm{g} ; \mathrm{jt}-\mathrm{g}_{\mathrm{t}}\right|$, where $\mathrm{w}$; are value added weights, $g$; and $g$ are one year growth rates of individual industrial sectors and GDP respectively. This index ranges between zero (when all sectors grow at the same rate as the aggregate and hence there is no structural change) and one. Calculated based on 12 sectors: agriculture, mining and quarrying, manufacturing, construction, gas electricity and water, transport and communication, distributive trades, banking and insurance, dwellings, professional and scientific, miscellaneous services, and public administration. 1870-1938: using component series from Feinstein (1972), Table 8, p. T24-5, Table 51, p. T111-3, Table 53, p. T116-7; 1947-99; from series at 〈http://www.statistics.gov.uk/statbase/TSD/timezone.asp〉, and various issues of CSO United Kingdom National Accounts.

World trade volume. 1881-1950: Calculated from Lewis (1952), Table 1, p. 106-7 and Table 2, p. 117-8; 1950-99: World Trade Organization <http://www.wto.org/ english/res_e/statis_e/statis_e.htm >; 1870-81: world trade value index from Tinbergen (1956), Table iA, deflated using price index calculated from Lewis.

\section{Data Source References}

Bain, G. S. and Price, R. (1980). Profiles of Union Growth. Oxford: Blackwell. Board of Trade (1912). Report on Trade Unions in 1908-1910. London: HMSO.

Boyer, G. R. and Hatton, T J. (2002). New estimates of British unemployment, 1870-1913. Journal of Economic History 62, pp. 643-75.

Burns, E. M. (1941). British Unemployment Programs, 1920-38. Washington, DC: Social Science Research Council.

Central Statistical Office (annual), United Kingdom National Accounts. London: HMSO.

Church, R. (1986). The History of the British Coal Industry, vol. 3. Oxford: Clarendon Press.

Department of Employment (1971). British Labour Statistics: Historical Abstract 1886-1968. London: HMSO.

Department of Trade and Industry (2000). Digest of UK Energy Statistics. London: HMSO.

Feinstein, C. H. (1972). National Income, Expenditure and Output of the United Kingdom, 1855-1965. Cambridge: Cambridge University Press.

Feinstein, C. H. (1995). Changes in nominal wages, the cost of living, and real wages in the United Kingdom over two centuries, 1780-1990. In P. Scholliers and V. Zamagni (eds), Labour's Reward. Aldershot: Edward Elgar.

Jenkins, G. (1986). Oil Economists' Handbook. Barking: Elsevier.

Lewis, W A. (1952). World production prices and trade, 1870-1960. Manchester School 20, pp. 105-38.

Metcalf, D., Nickell, S. J. and Floros, N. (1980). Still searching for an explanation of unemployment in interwar Britain. Discussion Paper no. 71, Centre For Labour Economics, LSE. 
Milner, S. (1994). Charting the coverage of collective pay-setting institutions: 1895-1990. Discussion Paper 215, Centre for Economic Performance, LSE.

Office of National Statistics. Economic Trends Annual Supplement (various issues), London: HMSO.

Raehsler, R. (1993). An empirical analysis of the British economy and labor union formation from 1870 to 1914. Unpublished Ph.D thesis, University of Iowa.

Royal Commission on Labour (1892). Rules and Associations of Employers and of Employed XXXVI. Great Britain: Parliamentary Papers.

Southall, H. (1998). The economics of mutuality: an analysis of trade union welfare systems in 19th century Britain. Unpublished manuscript.

Supple, B. (1987). The History of the British Coal Industry, vol. 4. Oxford:

Clarendon Press.

Tinbergen, J. (1956). Business Cycles in the United Kingdom, 18JO-1914. Amsterdam: North Holland. 